\title{
Characterization of Specific Membrane Fatty Acids as Chemotaxonomic Markers for Sulfate-Reducing Bacteria Involved in Anaerobic Oxidation of Methane
}

Article in Geomicrobiology · July 2003

DOI: 10.1080/01490450303894

CITATIONS

219

4 authors, including:

Marcus Elvert

Universität Bremen

138 PUBLICATIONS 6,271 CITATIONS

SEE PROFILE

Bo Barker Jørgensen

Aarhus University

528 PUBLICATIONS 44,117 CITATIONS

SEE PROFILE
READS

529
Katrin Knittel

Max Planck Institute for Marine Microbiology

230 PUBLICATIONS 12,503 CITATIONS

SEE PROFILE

Some of the authors of this publication are also working on these related projects:

Non-methane hydrocarbon degradation View project

Phospholipids in ODP Leg 190 samples (Table 2), supplement to: Zink, Klaus-Gerhard; Wilkes, Heinz; Disko, Ulrich; Elvert, Marcus; Horsfield, Brian (2003): Intact phospholipids - microbial life markers in marine deep subsurface sediments. Organic Geochemistry, 34(6), 755-769 View project 


\title{
Characterization of Specific Membrane Fatty Acids as Chemotaxonomic Markers for Sulfate-Reducing Bacteria Involved in Anaerobic Oxidation of Methane
}

\author{
MARCUS ELVERT \\ Max Planck Institute for Marine Microbiology \\ Department of Biogeochemistry \\ Bremen, Germany
}

\begin{abstract}
ANTJE BOETIUS
Alfred Wegener Institute for Polar and Marine Research

Department of Geochemistry

Bremerhaven, Germany

International University Bremen

Bremen, Germany
\end{abstract}

\section{KATRIN KNITTEL BO BARKER JØRGENSEN}

Max Planck Institute for Marine Microbiology

Department of Biogeochemistry

Bremen, Germany

\begin{abstract}
Membrane fatty acids were extracted from a sediment core above marine gas hydrates at Hydrate Ridge, NE Pacific. Anaerobic sediments from this environment are characterized by high sulfate reduction rates driven by the anaerobic oxidation of methane $(A O M)$. The assimilation of methane carbon into bacterial biomass is indicated by carbon isotope values of specific fatty acids as low as $-103 \%$ o. Specific fatty acids released from bacterial membranes include $C_{16: 1 \omega 5 c}, C_{17: 1 \omega 6 c}$, and cy $C_{17: 0 \omega 5,6}$, all of which have
\end{abstract}

Received 2 February 2002; accepted 7 April 2003.

We thank the officers, crew, and shipboard scientific party for excellent support during RV SONNE cruise SO-148/1. We are especially indebted to Dirk Rickert (GEOMAR, Kiel, Germany) for his help with sample handling and transport during and after the cruise. We also thank André Lipski (Universität Osnabrück, Germany) who provided literature data about $\mathrm{C}_{16: 1 \omega 5 \mathrm{c}}$ fatty acid-producing bacteria and specific taxa information on SRB. Beth Orcutt, Jutta Niggemann, and Solveig Bühring provided fruitful comments on an earlier version of the manuscript. Constructive criticism by two anonymous reviewers was highly appreciated. This study was part of the programs TECFLUX II (TECtonically induced FLUXes, FN 03G0148A) and MUMM (Mikrobielle UMsatzraten von Methan in gashydrathaltigen Sedimenten, FN 03G0554A) supported by the Bundesministerium für Bildung und Forschung (BMBF, Germany). Further support was provided from the Max-Planck-Gesellschaft (Germany). This is publication GEOTECH-16 of the program GEOTECHNOLOGIEN of the BMBF and the Deutsche Forschungsgemeinschaft (Germany).

Address correspondence to Marcus Elvert, Research Center Ocean Margins, University of Bremen, Department of Organic Geochemistry, Post Office Box 330 440, D-28334 Bremen, Germany. E-mail: melvert@ uni-bremen.de 
been fully characterized by mass spectrometry. These unusual fatty acids continuously display the lowest $\delta^{13} C$ values in all sediment horizons and two of them are detected in high abundance (i.e., $C_{16: 1 \omega 5 c}$ and $c y C_{17: 0 \omega 5,6}$ ). Combined with microscopic examination by fluorescence in situ hybridization specifically targeting sulfate-reducing bacteria $(S R B)$ of the Desulfosarcina/Desulfococcus group, which are present in the aggregates of AOM consortia in extremely high numbers, these specific fatty acids appear to provide a phenotypic fingerprint indicative for SRB of this group. Correlating depth profiles of specific fatty acid content and aggregate number in combination with pore water sulfate data provide further evidence of this finding. Using mass balance calculations we present a cell-specific fatty acid pattern most likely displaying a very close resemblance to the still uncultured Desulfosarcina/Desulfococcus species involved in AOM.

Keywords anaerobic oxidation of methane, cyclopropane fatty acid, dimethyl disulfide adducts, dimethyloxazoline derivatives, fatty acid methyl esters, methanotrophic archaea, stable carbon isotopes, sulfate-reducing bacteria, syntrophic consortia

\section{Introduction}

Abundant information now exists about lipid biomarkers associated with the process of anaerobic oxidation of methane (AOM) in the marine environment (e.g., Elvert et al. 2000; Hinrichs et al. 2000; Pancost et al. 2000; Thiel et al. 2001). Lipids derived from AOM are evident by their highly ${ }^{13} \mathrm{C}$-depleted carbon isotopic compositions due to the unequivocally low and characteristic isotopic signal of the substrate methane ( -50 to $-110 \%$; Whiticar 1999). Therefore, methane carbon incorporation into microbial biomass can be regarded as a natural ${ }^{13} \mathrm{C}$-depleted tracer experiment. Recent studies provided evidence that consortia of archaea and sulfate-reducing bacteria (SRB) mediate the process of AOM in various methane seep environments (Boetius et al. 2000; Orphan et al. 2001; Michaelis et al. 2002). Most of the studies on lipid biomarkers associated with AOM primarily focused on the presence and carbon isotopic compositions of a set of biomarkers derived from archaea anaerobically oxidizing methane: crocetane, pentamethylicosane, archaeol, hydroxyarchaeol, and glycerol tetraethers (Elvert et al. 1999; Hinrichs et al. 1999; Thiel et al. 1999; Pancost et al. 2001b; Schouten et al. 2001). In contrast, existing data on lipid biomarkers proposed to derive from the SRB partners involved in AOM suggest that SRB biomarkers are highly diverse and include straight chain and methyl-branched fatty acids and alcohols (Thiel et al. 1999; Hinrichs et al. 2000; Pancost et al. 2000; Elvert et al. 2001; Zhang et al. 2002) as well as mono- and dialkyglycerolethers (Hinrichs et al. 2000; Orphan et al. 2001; Pancost et al. 2001a; Werne et al. 2002).

To date, most of the studies on AOM-associated lipid biomarkers have been limited to single samples and only some of the published data provided total fatty acid patterns (Hinrichs et al. 2000; Zhang et al. 2002). Therefore, the present study aims to extend the inventory of membrane fatty acids usable to monitor SRB involvement in AOM in the modern and the fossil record. We investigated a sediment core with high AOM activity from southern Hydrate Ridge (Cascadia convergent margin, NE Pacific), off the coast of Oregon. Hydrate Ridge is a cold seep environment accompanied by methane hydrates that often occur just a few centimeters beneath the sediment surface (Suess et al. 1999, 2001). The environment is characterized by high fluid flow (Torres et al. 2002), steep gradients of pore water sulfate (Boetius et al. 2000; Elvert et al. 2001), high rates of AOM and sulfate reduction (Boetius et al. 2000; Treude et al. submitted), ${ }^{13} \mathrm{C}$-depleted lipid biomarkers of archaeal and bacterial origin (Elvert et al. 1999; Boetius et al. 2000; Elvert et al. 2001), and ${ }^{13}$ C-depleted authigenic carbonates (Kulm et al. 1986; Ritger et al. 1987; Bohrmann et al. 1998; Greinert et al. 2001). These cold seep sediments harbor aggregates of AOM consortia composed of archaea related to the order Methanosarcinales and SRB representing close relatives of Desulfosarcina/Desulfococcus species of the $\delta$-proteobacteria (Boetius et al. 
2000). The observed aggregates account for more than $90 \%$ of all detected archaea and $\mathrm{SRB}$ in the sediments and therefore sediments of this setting can be considered as a natural enrichment culture of AOM consortia. Our special emphasis was the characterization of membrane fatty acids as reproducible and stable chemotaxonomic markers for the yet uncultured Desulfosarcina/Desulfococcus species in AOM consortia in methane-rich environments. Their specific fingerprint may be used in the future to examine the presence and activity of these and closely related species both in field studies and laboratory experiments.

\section{Materials and Methods}

\section{Sample Collection and Storage}

Sediment samples were obtained during the RV SONNE cruise SO-148/1 in August 2000 at the crest of southern Hydrate Ridge $\left(44^{\circ} 34^{\prime} \mathrm{N}, 125^{\circ} 09^{\prime} \mathrm{W} ; 780 \mathrm{~m}\right.$ water depth) from an area of active methane venting using a video-guided multiple corer (station 19-2). Upon recovery, the sediment core, covered by a white mat of giant sulfide-oxidizing bacteria (Beggiatoa), was sliced into depth intervals of $2 \mathrm{~cm}(0-10 \mathrm{~cm})$ and $3 \mathrm{~cm}(10-19 \mathrm{~cm})$. Each sediment section was transferred into a pre-cleaned $20 \mathrm{ml}$ glass vial and stored frozen at $-30^{\circ} \mathrm{C}$ until lipid extraction. Sediment samples for the determination of AOM aggregates in the upper $10 \mathrm{~cm}$ were obtained from a replicate sediment core at station 19-2 subsampled in 1-cm intervals. The samples for cell numbers were processed and analyzed by microscopic examination using fluorescence in situ hybridization (FISH) as described previously (Boetius et al. 2000; Knittel et al. 2003, this issue).

\section{Extraction of Sediment Samples and Preparation of Fatty Acid Methyl Esters (FAMES)}

Lipids were extracted by ultrasonication of sediment samples ( 8 to $10 \mathrm{~g}$ of wet sediment) at $0^{\circ} \mathrm{C}$ (ice-cooling) using (I) $25 \mathrm{ml}$ of methanol/dichloromethane $(2: 1, \mathrm{v} / \mathrm{v})$, (II) $25 \mathrm{ml}$ of methanol/dichloromethane (1:2, v/v), (III) and (IV) $25 \mathrm{ml}$ of dichloromethane. Internal standards representing different compound classes $\left(5 \alpha(\mathrm{H})\right.$-cholestane, $n$ - $\mathrm{C}_{36}, 2$-nonadecanon, nonadecanol, nonadecanoic acid) were added at known concentrations and $\delta^{13} \mathrm{C}$ values prior to extraction. The extracts were pooled and partitioned against pre-extracted $0.05 \mathrm{M}$ $\mathrm{KCl}$-solution $(25 \mathrm{ml})$ in a separatory funnel. The lower organic phase was collected and the solvent evaporated, yielding a total lipid extract (TLE). An aliquot of the TLE was transferred to a 10-ml glass vial, evaporated under a stream of nitrogen close to dryness and saponified with $2 \mathrm{ml} 6 \% \mathrm{KOH}$ in $\mathrm{MeOH}$. The reaction was maintained at $80^{\circ} \mathrm{C}$ for $3 \mathrm{~h}$. After cooling, the mixture was diluted with $2 \mathrm{ml} 0.05 \mathrm{M} \mathrm{KCl}$-solution. Neutral lipids were released from the basic mixture by extracting four times with $2 \mathrm{ml} n$-hexane. The remaining aqueous reaction mixture was treated with $25 \% \mathrm{HCl}$ to $\mathrm{pH} 1$ and free fatty acids were extracted four times with $n$-hexane $(2 \mathrm{ml}$ each). The combined extracts were dried under a stream of nitrogen and free fatty acids were reacted with $1 \mathrm{ml} 14 \% \mathrm{BF}_{3}$ in $\mathrm{MeOH}$ at $70^{\circ} \mathrm{C}$ for $1 \mathrm{~h}$ to form FAMES. After cooling, the mixture was extracted four times with $2 \mathrm{ml} n$-hexane in the presence of $1 \mathrm{ml} 0.05 \mathrm{M} \mathrm{KCl}$-solution. Combined extracts were evaporated under a stream of nitrogen, redissolved in $100 \mu \mathrm{l} n$-hexane, and stored at $-20^{\circ} \mathrm{C}$ until further analysis.

\section{Preparation of Dimethyl Disulfide (DMDS) Adducts}

The double bond positions in FAMES were determined by analysis as their DMDS adducts according to the method of Nichols et al. (1986). Briefly, 1/2 aliquot of a selected sample 
dissolved in $50 \mu \mathrm{l} n$-hexane was treated with $100 \mu \mathrm{l}$ DMDS (Aldrich Chemicals, Steinheim, Germany) and $20 \mu \mathrm{l}$ of iodine solution ( $6 \% \mathrm{w} / \mathrm{v}$ in diethyl ether). The mixture was flushed with nitrogen and formation of DMDS adducts was carried out in a 2-ml screw-cap (teflonlined) glass vial at $50^{\circ} \mathrm{C}$ for $48 \mathrm{~h}$. After $48 \mathrm{~h}$, the mixture was cooled and diluted with $500 \mu \mathrm{l}$ of $n$-hexane. The excess of iodine was reduced by addition of $500 \mu \mathrm{l}$ sodium thiosulfate $(5 \% \mathrm{w} / \mathrm{v}$ in water). The organic phase was removed and the aqueous phase extracted twice with $500 \mu \mathrm{l}$ of $n$-hexane. Combined organic phases were evaporated under a gentle stream of nitrogen and diluted with $50 \mu 1$ of $n$-hexane prior to GC-MS analysis.

\section{Preparation of 4,4-Dimethyloxazoline (DMOX) Derivatives}

Ring positions in FAMES were determined by analysis of DMOX derivatives according to the method of Fay and Richli (1991). Briefly, $500 \mu$ l of 2-amino-2-methyl-1-propanol were added to a dried FAMES fraction (1/2 aliquot of a selected sample) in a 5-ml screw-cap (teflon-lined) reaction vial. The vial was flushed with nitrogen, tightly closed, and placed in a heating block at $190^{\circ} \mathrm{C}$ overnight. On the next day, the vial was cooled to room temperature. Then $2 \mathrm{ml}$ diethyl ether- $n$-hexane $(1: 1, \mathrm{v} / \mathrm{v})$ and $2 \mathrm{ml}$ of water were added to the reaction mixture. The vial was vigorously shaken and the organic phase removed. The extraction step was repeated twice with $2 \mathrm{ml}$ of fresh solvent. Combined organic phases were washed with water $(2 \mathrm{~mL})$, dried with anhydrous sodium sulfate, and evaporated to dryness in a gentle stream of nitrogen. Finally, DMOX derivatives were dissolved in $100 \mu l n$-hexane prior to GC-MS analysis.

\section{Gas Chromatography $(G C)$}

Concentrations of FAMES were determined by GC analysis using a 50-m apolar HP-5 fused silica capillary column $(0.32 \mathrm{~mm}$ internal diameter [ID], film thickness $0.17 \mu \mathrm{m}$; Hewlett Packard) in a HP 5890 Series II GC equipped with a split/splitless injector operated in splitless mode and a flame ionization detector (FID). Initial oven temperature was $60^{\circ} \mathrm{C}$, held for $1 \mathrm{~min}$, subsequently increased to $150^{\circ} \mathrm{C}$ at a rate of $10^{\circ} \mathrm{C} / \mathrm{min}$, then raised to $310^{\circ} \mathrm{C}$ at a rate of $4^{\circ} \mathrm{C} / \mathrm{min}$ and held at $310^{\circ} \mathrm{C}$ for $25 \mathrm{~min}$. The carrier gas was He at a constant flow rate of $2.0 \mathrm{ml} / \mathrm{min}$. The injector temperature was set at $290^{\circ} \mathrm{C}$ and the detector at $300^{\circ} \mathrm{C}$. Concentration for each compound was calculated relative to the internal standard present within the respective FAME fraction.

\section{Gas Chromatography-Mass Spectrometry (GC-MS)}

FAMES were identified by GC-MS using a Thermoquest Trace GC interfaced to a Finnigan Trace MS. The GC-MS was operated in electron impact (EI+)-mode at $70 \mathrm{eV}$ with a full scan mass range of $m / z$ 40-900 (1.5 scans per second). The GC was equipped with a HP-5 MS fused silica capillary column (60 m, $0.32 \mathrm{~mm}$ ID; Hewlett Packard) coated with a cross-linked methyl silicone phase (film thickness $0.25 \mu \mathrm{m}$ ). The detector was set at $350 \mathrm{~V}$, the interface was $300^{\circ} \mathrm{C}$, and He was used as carrier gas (constant flow: $1.4 \mathrm{ml} / \mathrm{min}$ ). The samples were injected in splitless mode (hot needle technique; injector temperature: $290^{\circ} \mathrm{C}$ ) and subjected to the same temperature program given for GC measurements, with the exception of an elevated hold time of $50 \mathrm{~min}$ at $310^{\circ} \mathrm{C}$.

\section{Gas Chromatography-Isotope Ratio Mass Spectrometry (GC-IRMS)}

Carbon isotope compositions of FAMES were determined by coupled GC-IRMS. The mass spectrometer (Finnigan Delta plus) was connected via a Finnigan Combustion Interface III to a HP 6890 Series GC equipped with a $50 \mathrm{~m}$ HP-5 (0.32 mm ID, $0.17 \mu \mathrm{m}$ stationary 
phase, Hewlett-Packard). The carrier gas was He at a constant flow rate of $1.5 \mathrm{ml} / \mathrm{min}$. The samples were injected in splitless mode (injector temperature: $290^{\circ} \mathrm{C}$ ) and subjected to the same temperature program given for GC-MS measurements. The oxidation oven of the combustion interface was operated at $940^{\circ} \mathrm{C}$; the reduction oven at $640^{\circ} \mathrm{C}$. Carbon isotope ratios are reported in the $\delta$ notation as per mil (\%o) deviation from the Pee Dee Belemnite standard (PDB). Internal standards (nonadecanoic acid, $n-\mathrm{C}_{26}$ ) within each run were used to monitor reproducibility and precision during this study. $\delta^{13} \mathrm{C}$ values reported have an analytical error of less than $\pm 1.0 \%$ and are corrected for the introduction of additional carbon atoms during derivatization with $\mathrm{BF}_{3} / \mathrm{MeOH}$.

\section{Results}

\section{Fatty Acid Identification and Abundance}

A typical fatty acid chromatogram of this study is shown in Figure 1. As of all other sediment horizons, the chromatogram is dominated by a cluster of monounsaturated $\mathrm{C}_{16: 1}$ fatty acids (i.e., $\mathrm{C}_{16: 1 \omega 7 \mathrm{c}}, \mathrm{C}_{16: 1 \omega 7 \mathrm{t}}$, and $\mathrm{C}_{16: 1 \omega 5 \mathrm{c}}$ ), accounting for approximately $50 \%$ of the total fatty acids present. The most abundant fatty acid in nearly all sediment horizons is $\mathrm{C}_{16: 1 \omega 5 \mathrm{c}}$. Other prominent fatty acids include $\mathrm{C}_{14: 0}, a i-\mathrm{C}_{15: 0}, \mathrm{C}_{16: 0}$, and $\mathrm{C}_{18: 1 \omega 7 \mathrm{c}}$ (Table 1).

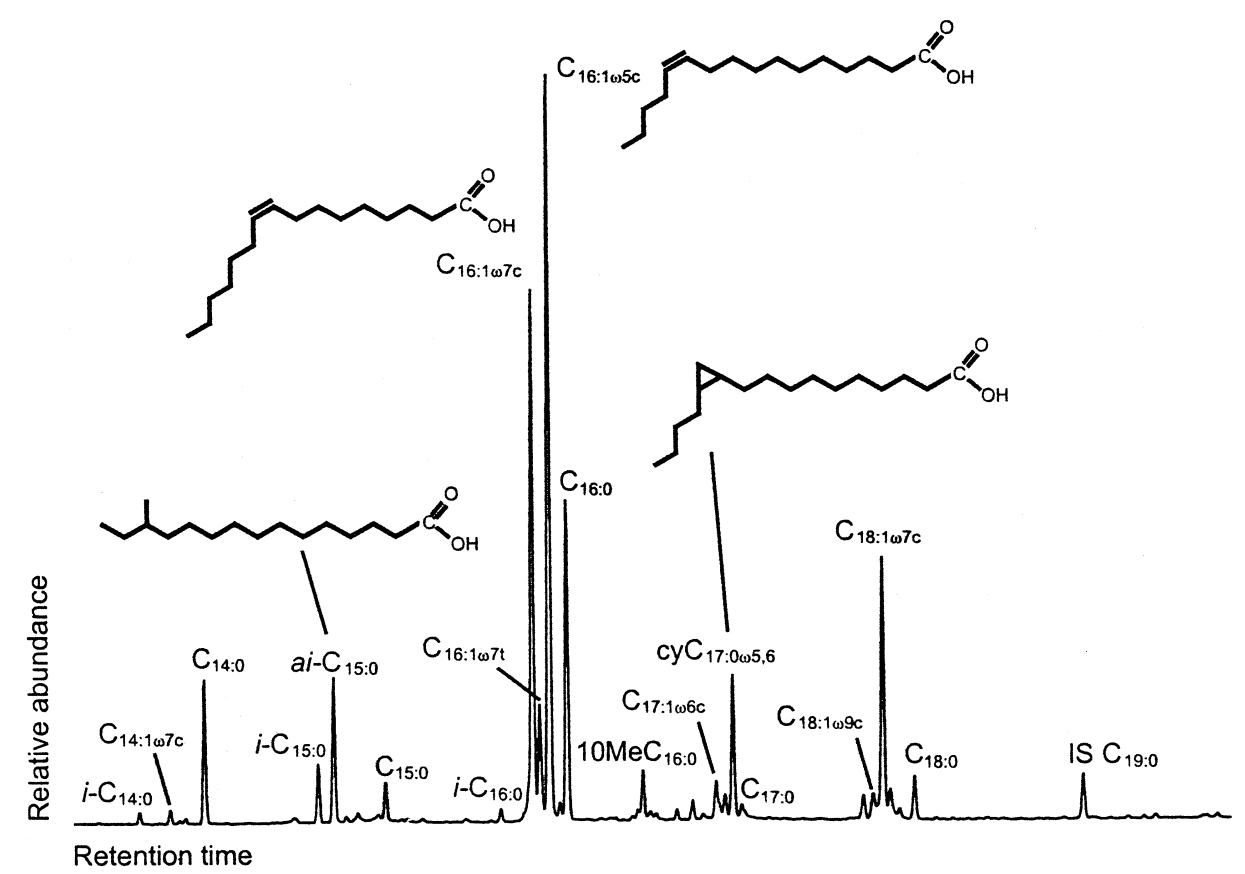

FIGURE 1 Partial gas chromatogram of fatty acids (as FAMES) obtained from an anaerobic sediment section (4-6 cm sediment depth) within a core covered by a white Beggiatoa mat. Structures of key fatty acids as naturally occurring in bacterial membranes are illustrated. Fatty acid abbreviations characterize carbon chain length, number of double bonds, and position of the double bond from the aliphatic $(\omega)$ end of the molecule. Configuration of the double bond is indicated by "c" for $c i s$ and " $\mathrm{t}$ " for trans. Thus, for example, $\mathrm{C}_{16: 1 \omega 5 \mathrm{c}}$ represents cis-11-hexadecenoic acid. Iso (i) and anteiso (ai) FAMES are methyl-branched one and two carbon atoms from the aliphatic end, respectively. The cyclopropane fatty acid (CFA) is designated as "cy", with the ring positioned at the two carbon atoms indicated. 


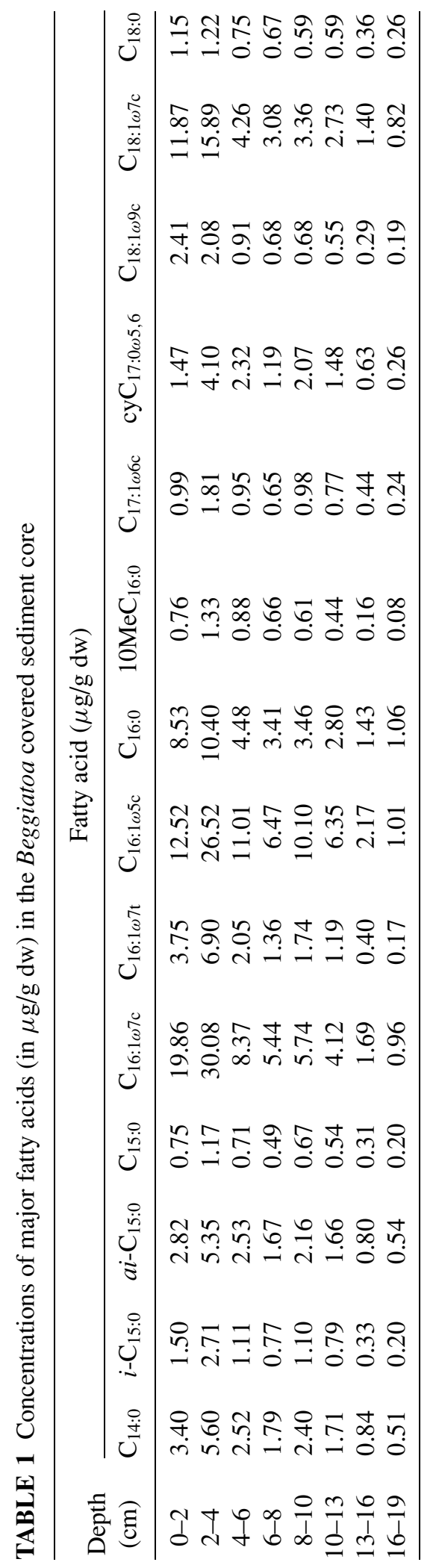




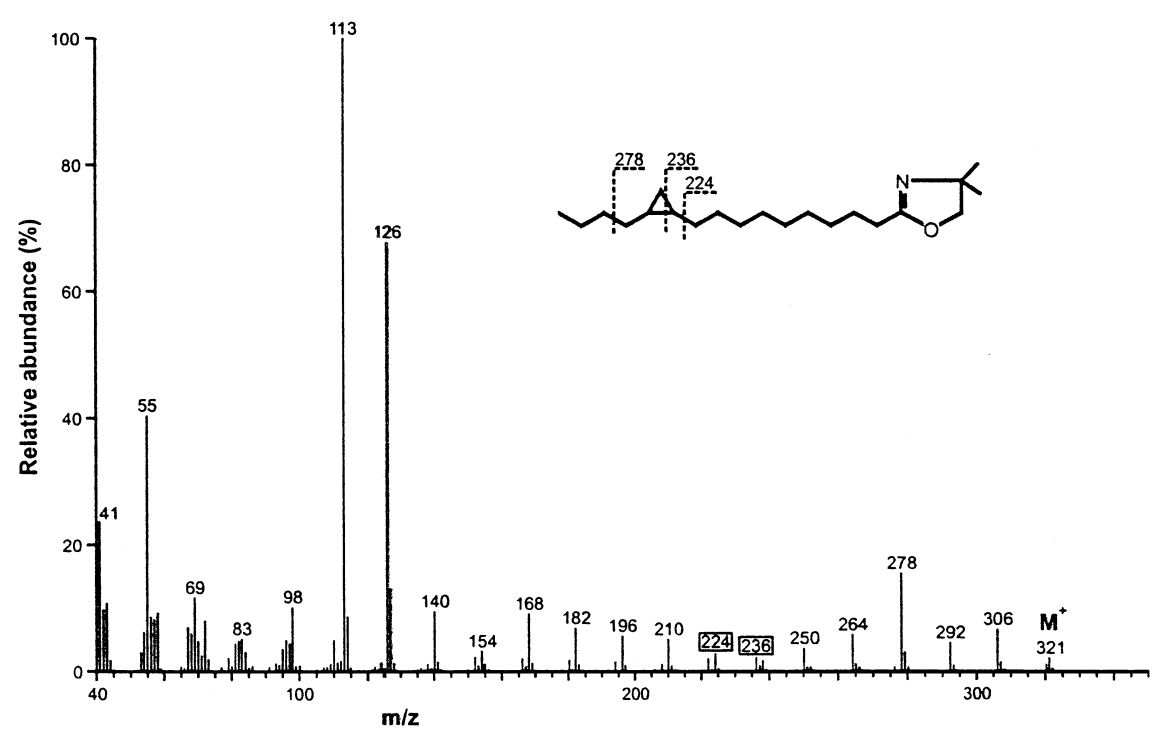

FIGURE 2 Electron-impact mass spectrum of the DMOX derivative of 11,12-methylenehexadecanoic acid $\left(\mathrm{cyC}_{17: 0 \omega 5,6}\right)$.

Interestingly, all fatty acid fractions also contain relatively high amounts of an unknown fatty acid eluting slightly before $\mathrm{C}_{17: 0}$ with an equivalent chain length (ECL) of 16.95 (HP-5). Although this particular fatty acid showed similar FAME mass spectral information as obtained for an unsaturated $\mathrm{C}_{17: 1}$ fatty acid, a double bond was not revealed by the addition of DMDS. This indicated the presence of a cyclopropane ring in the fatty acid molecule. Indeed, the unknown fatty acid present in the anaerobic methane-rich sediments was identified as 11,12-methylene-hexadecanoic acid $\left(\mathrm{cyC}_{17: 0 \omega 5,6}\right)$ by its specific retention time and its mass spectral data of the DMOX derivative (Figure 2). Prominent peaks of the DMOX derivative are at $m / z=113$ as a product of McLafferty rearrangement and at $m / z=126$ probably formed by cyclization-displacement (see Spitzer 1997 for a review). The cyclopropane ring at position $\omega 5,6$ is indicated by a mass difference of 12 amu instead of 14 amu between $m / z=224$ and $m / z=236$ accompanied by an intense ion fragment at $m / z=278$. The same characteristic ion fragments of $m / z=224$ and $m / z=236$ were observed for the DMOX derivative of $\mathrm{C}_{16: 1 \omega 5 \mathrm{c}}$, additionally confirming the cyclopropane ring position at $\omega 5,6$.

\section{Stable Carbon Isotopic Compositions}

$\delta^{13} \mathrm{C}$ measurements of fatty acids examined from the anaerobic sediment horizons revealed a repetitive carbon isotopic pattern that is shown in Figure 3. The fatty acid profiles of all samples analyzed display the lowest, most depleted $\delta^{13} \mathrm{C}$ values for the fatty acids $\mathrm{C}_{16: 1 \omega 5 \mathrm{c}}$, ${ }^{c y C} \mathrm{C}_{17: 0 \omega 5,6}$, and $\mathrm{C}_{17: 1 \omega 6 \mathrm{c}}$ (in order of abundance). $\delta^{13} \mathrm{C}$ values for these fatty acids in the sediment core range from -75 to $-96 \%$ for $\mathrm{C}_{16: 1 \omega 5 \mathrm{c}}$ (Average: $-90 \%$ ), from -94 to $-103 \%$ o for $\mathrm{cyC}_{17: 0 \omega 5,6}$ (Average: $-100 \%$ ), and from -65 to $-88 \%$ o for $\mathrm{C}_{17: 1 \omega 6 \mathrm{c}}$ (Average: $-80 \%$ ) (Table 2). In these three fatty acids the lowest $\delta^{13} \mathrm{C}$ value of $-103 \%$ was measured for cyC $\mathrm{C}_{17: 0 \omega 5,6}$ in the 4-6-cm sediment section, whereas the highest $\delta^{13} \mathrm{C}$ value of $-65 \%$ o was obtained for $\mathrm{C}_{17: 1 \omega 6 \mathrm{c}}$ in the uppermost depth interval $(0-2 \mathrm{~cm})$. All other fatty acids also show ${ }^{13} \mathrm{C}$-depleted carbon isotopic compositions but they do not exhibit as strong ${ }^{13} \mathrm{C}$-depletions 


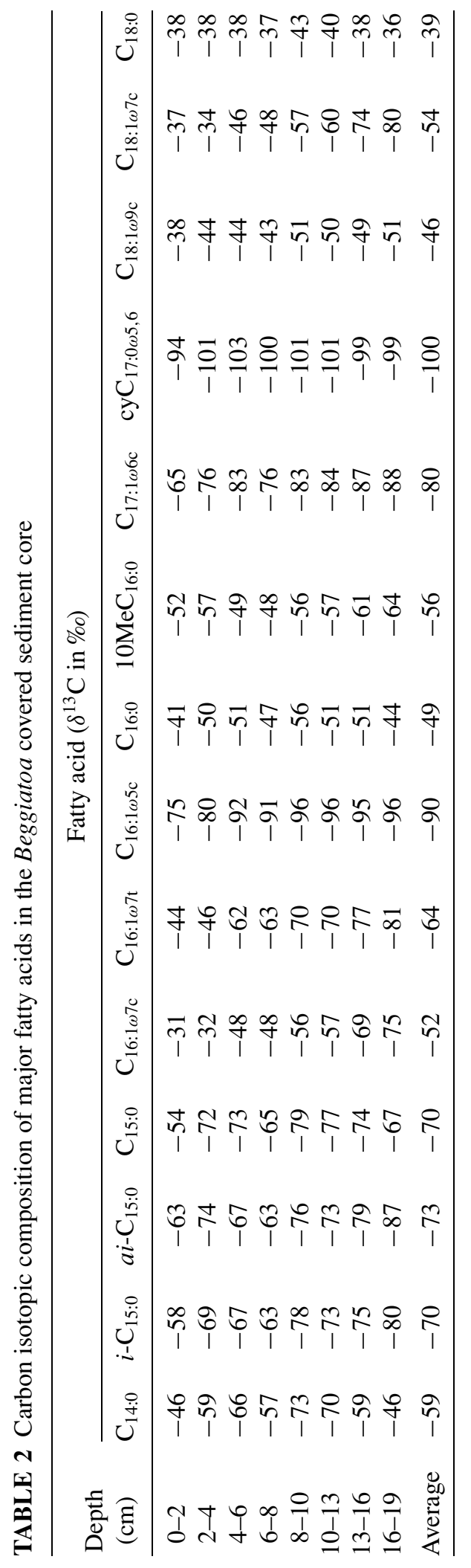




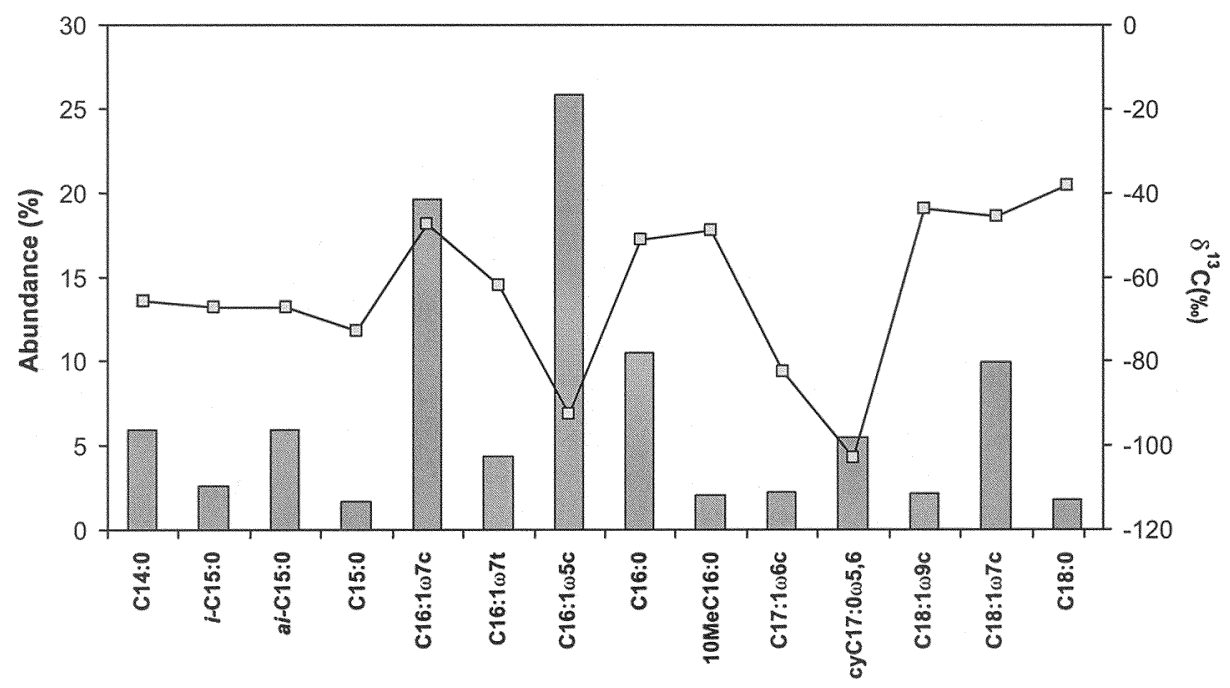

FIGURE 3 Relative abundance (dark gray bars) and carbon isotopic composition (light gray squares) of major fatty acids obtained in the $4-6 \mathrm{~cm}$ sediment section.

as observed for $\mathrm{C}_{16: 1 \omega 5 \mathrm{c}}, \mathrm{cyC}_{17: 0 \omega 5,6}$, and $\mathrm{C}_{17: 1 \omega 6 \mathrm{c}}$ in a respective sediment section. In contrast to the above, the two major fatty acids $C_{16: 1 \omega 7 \mathrm{c}}$ and $\mathrm{C}_{18: 1 \omega 7 \mathrm{c}}$ show relatively enriched $\delta^{13} \mathrm{C}$ values between -31 and $-37 \%$ in the upper $4 \mathrm{~cm}$ of the sediment core. This probably indicates strong contributions to the content of $\mathrm{C}_{16: 1 \omega 7 \mathrm{c}}$ and $\mathrm{C}_{18: 1 \omega 7 \mathrm{c}}$ from the white mat of sulfide-oxidizing Beggiatoa, which use pore water $\mathrm{CO}_{2}$ strongly mixed with marine seawater as carbon source and that have been shown to contain high amounts of these two fatty acids (Carsten Schubert, unpublished data).

\section{Discussion}

\section{Fatty Acid Fingerprint of Desulfosarcina/Desulfococcus Species Involved in AOM}

Our fatty acid data clearly show an enrichment of unusual fatty acids (i.e., $C_{16: 1 \omega 5 c}, C_{17: 1 \omega 6 c}$, and cy $\left.\mathrm{C}_{17: 0 \omega 5,6}\right)$ above marine gas hydrates in the fluid flow-impacted sediments of Hydrate Ridge (Figure 1). The high abundance of the $C_{16: 1 \omega 5 c}$ fatty acid is an exceptional finding because the anaerobic fatty acid synthesis desaturase pathway in bacteria preferentially leads to the production of $\omega 7$ isomers (Alexandrino et al. 2001). Additionally, the unusual fatty acids reveal very low $\delta{ }^{13} \mathrm{C}$ values throughout the sediment core (Table 2, Figure 3), indicating a bacterial source involved in AOM at this setting. Indeed, Hydrate Ridge sediments are characterized by a predominance of SRB of the Desulfosarcina/Desulfococcus group as part of anaerobic methane-oxidizing consortia (Boetius et al. 2000), also recently described as Seep SRB1 group (see Knittel et al. 2003, this issue). Accordingly, depth profiles of specific fatty acid contents (i.e., $\mathrm{C}_{16: 1 \omega 5 \mathrm{c}}$ and $\mathrm{cyC}_{17: 0 \omega 5,6}$ ) and $\mathrm{AOM}$ aggregate number in the samples are in very good agreement (Figure 4), permitting for the first time a positive correlation between these parameters $\left(r^{2}\left[\mathrm{C}_{16: 1 \omega 5 \mathrm{c}}\right]=0.66 ; r^{2}\left[\mathrm{cyC}_{17: 0 \omega 5,6}\right]=0.62\right)$. Fatty acid abundance and aggregate number increase from the sediment surface to the $2-4 \mathrm{~cm}$ sediment horizon and decrease simultaneously in the deeper part of the sediment core. Highest fatty acid contents obtained are 26.52 and $4.10 \mu \mathrm{g} / \mathrm{g}$ sediment dry weight (dw) for $\mathrm{C}_{16: 1 \omega 5 \mathrm{c}}$ and $\mathrm{cyC}_{17: 0 \omega 5,6}$, respectively (Table 1 ), whereas aggregate abundance reaches a number of up to $11.4 \times 10^{7}$ per $\mathrm{cm}^{-3}$ in the samples that is similar to counts obtained in 


\section{fatty acids $(\mu \mathrm{g} / \mathrm{g} \mathrm{dw})$ aggregate number $\left(\times 10^{7} / \mathrm{cm}^{-3}\right)$ sulfate $(\mathrm{mmol} / \mathrm{l})$}

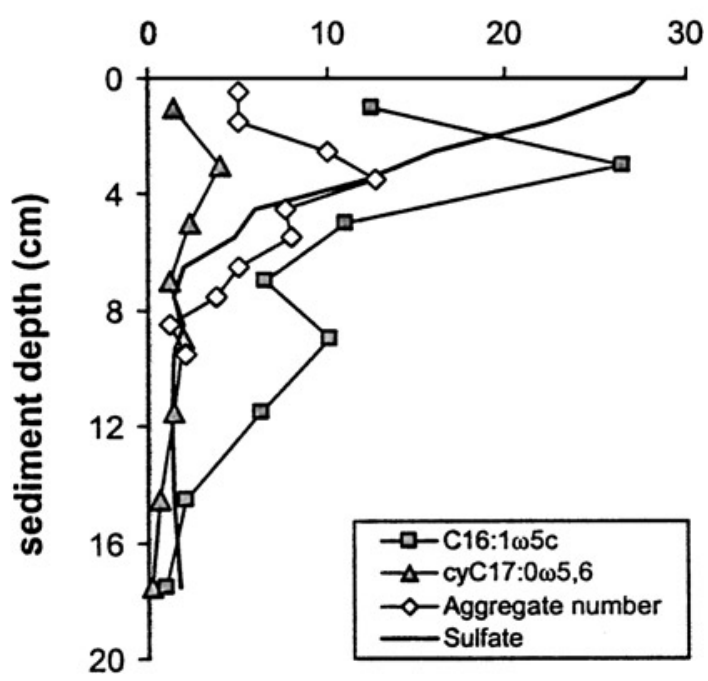

FIGURE 4 Depth profiles of specific membrane fatty acids derived from SRB (dark gray squares and triangles), aggregate number (white diamonds), and pore water sulfate (black line) within a core covered by a Beggiatoa mat. Pore water sulfate data have been kindly provided by Dirk Rickert (GEOMAR, Kiel, Germany).

previous studies (Boetius et al. 2000; Nauhaus et al. 2002). The maximum peaks co-occur in sediment sections where pore water sulfate is rapidly decreasing with depth and, thus, high sulfate reduction rates have been measured (Treude et al. submitted), which again suggests that both trends are strongly associated with AOM activity.

Culture studies have shown that different species of SRB in the marine environment are distinguishable by their specific fatty acid pattern. For instance, the appearance (relative fatty acid content $>10 \%$ ) of $10 \mathrm{MeC}_{16: 0}$ accompanied by cyC $\mathrm{C}_{17: 0 \omega 7,8}$ can be indicative for Desulfobacter species (Taylor and Parkes 1983; Dowling et al. 1986) although this same relation has recently also been encountered in Desulfobacula species (Kuever et al. 2001). Nevertheless, Desulfobacter species seem to be of minor importance in our samples since $10 \mathrm{MeC}_{16: 0}$ is present in low abundance, does not display a significant ${ }^{13} \mathrm{C}$-depleted carbon isotope signal, and is, perhaps more importantly, not accompanied by cyC $\mathrm{C}_{17: 0 \omega 7,8}$. Other fatty acids with clear specificity inferred from cultures are $i-\mathrm{C}_{17: 1 \omega 7 \mathrm{c}}$ as indicator for Desulfovibrio species (Taylor and Parkes 1983; Vainshtein et al. 1992) and $\mathrm{C}_{17: 1 \omega 6 \mathrm{c}}$, a fatty acid indicating Desulfobulbus species (Taylor and Parkes 1983; Parkes and Calder 1985) but which has also been found in considerable amounts in Desulforhabdus species as well as Desulforhopalus species (Knoblauch et al. 1999; Rütters et al. 2001). Whereas the fatty acid $i-\mathrm{C}_{17: 1 \omega 7 \mathrm{c}}$ was only detected in trace amounts in our samples, $\mathrm{C}_{17: 1 \omega 6 \mathrm{c}}$ is clearly detectable $(2.2 \%$ relative fatty acid content) and moreover carries a significant ${ }^{13} \mathrm{C}$-depleted carbon isotope value (Table 2). Desulfobulbus or other related $\mathrm{C}_{17: 1 \omega 6 \mathrm{c}}$-producing species contain high amounts of this compound of up to 60\% (Taylor and Parkes 1983; Parkes and Calder 1985; Knoblauch et al. 1999) but they contribute to less than $2 \%$ of all bacteria at Hydrate Ridge (Knittel et al. 2003, this issue). So far, they have not been found to be a partner in AOM consortia. Hence, it is either likely that free-living Desulfobulbus or other related $\mathrm{C}_{17: 1 \omega 6 \mathrm{c}}$-producing species 
use a ${ }^{13} \mathrm{C}$-depleted carbon substrate excreted from the $\mathrm{AOM}$ consortia or that $\mathrm{C}_{17: 1 \omega 6 \mathrm{c}}$ may be produced in small amounts by SRB of the genus Desulfosarcina/Desulfococcus involved in AOM.

The positive correlation of $\mathrm{C}_{16: 1 \omega 5 \mathrm{c}}$ and $\mathrm{cyC}_{17: 0 \omega 5,6}$ fatty acid content with aggregate number obtained by FISH is remarkable (Figure 4). ${ }^{14} \mathrm{C}$-labeling studies have shown that formation of cyclopropane fatty acids (CFAs) is performed by the transfer of a methyl group from $S$-adenosylmethionine to the double bond of an unsaturated fatty acid of a phospholipid molecule (Grogan and Cronan 1997), so that the $C_{16: 1 \omega 5 c}$ fatty acid bound in the phospholipid membrane of Desulfosarcina/Desulfococcus species would be transformed in situ to cy $\mathrm{C}_{17: 0 \omega 5,6}$. Thus, the appearance of $\mathrm{C}_{16: 1 \omega 5 \mathrm{c}}$ accompanied by cyC $\mathrm{C}_{17: 0 \omega 5,6}$ provides a highly specific fatty acid fingerprint of SRB of the genus Desulfosarcina/Desulfococcus involved in AOM. This finding would be new to the family Desulfobacteraceae to which the Desulfosarcina/Desulfococcus group belongs. In contrast, recent cultures of the relatives Desulfococcus multivorans and Desulfosarcina variabilis displayed no or insignificant contents of $\mathrm{C}_{16: 1 \omega 5 \mathrm{c}}$, respectively, and CFAs were almost below detection limit (Kohring et al. 1994; Rütters et al. 2001, 2002). The dominant monoenoic fatty acid $\mathrm{C}_{16: 1 \omega 5 \mathrm{c}}$ in methane-rich sediments of Hydrate Ridge has also been detected in significant amounts in three other genera of SRB, namely Desulfotalea, Desulfobulbus, and Desulforhopalus (Knoblauch et al. 1999; Rütters et al. 2001; Sass et al. 2002). But likewise, none of these culture studies revealed the presence of significant amounts of CFAs.

So far, only one report from a methane cold seep environment provided a total fatty acid pattern quite similar to the one shown in Figure 1 (Hinrichs et al. 2000). In combination with carbon isotope measurements of several fatty acids Hinrichs and co-workers showed that $\mathrm{C}_{16: 1 \omega 5 \mathrm{c}}, 10 \mathrm{MeC}_{16: 0}$, and an uncharacterized CFA were carrying the lowest $\delta^{13} \mathrm{C}$ values in sediments of the Santa Barbara Basin. This pattern points to two groups of $\mathrm{SRB}$ involved in AOM in these sediments which are in part closely-related to Desulfosarcina/Desulfococcus species found in our setting $\left(\mathrm{C}_{16: 1 \omega 5 \mathrm{c}}\right.$ and CFA) whereas others may be derived from Desulfobacter-like species $\left(10 \mathrm{MeC}_{16: 0}\right)$. Indeed, Orphan et al. (2001) were able to show that besides Desulfosarcina/Desulfococcus species other bacterial species, although rather peripherally related to known $\delta$-proteobacteria, are also involved in AOM.

In contrast to the results obtained by Hinrichs et al. (2000) and our study, fatty acid patterns from Gulf of Mexico gas hydrate-bearing sediments are not enriched in the specific fatty acids $\mathrm{C}_{16: 1 \omega 5 \mathrm{c}}, 10 \mathrm{MeC}_{16: 0}, \mathrm{C}_{17: 1 \omega 6 \mathrm{c}}$, or cyC $\mathrm{C}_{17: 0 \omega 5,6}$. Here iso- and anteiso-branched $\mathrm{C}_{15: 0}$ fatty acids predominantly carry the lowest $\delta^{13} \mathrm{C}$ values and thus, different SRB species or other bacteria play an important role in AOM in this setting (Zhang et al. 2002). The results from the Gulf of Mexico are, on the other hand, in good agreement with fatty acid results from the Mediterranean Ridge (Pancost et al. 2000) and the Black Sea (Thiel et al. 2001). The latter finding is quite remarkable considering that SRB of the Desulfosarcina/Desulfococcus group in AOM aggregates determined by FISH from the Black Sea microbial mats belong to the same SRB taxon as found in Hydrate Ridge sediments (Michaelis et al. 2002). This most likely points to different Desulfosarcina/Desulfococcus species as part of AOM consortia in these two settings.

\section{Mass Balance Calculation and Desulfosarcina/Desulfococcus Specific Fatty Acid Pattern}

Stable carbon isotope labeling of lipid biomarkers can be used to obtain information about the functioning of specific bacteria and - if quantitatively analyzed-about the importance of various microbial populations, metabolic pathways, and biogeochemical processes in the natural environment (Boschker and Middelburg 2002). This approach has been used for 
example in soils and sediments for the detection of methane-oxidizing bacterial populations (Boschker et al. 1998; Bull et al. 2000; Crossmann et al. 2001) and the degradation of aromatic hydrocarbons (Hanson et al. 1999; Johnson et al. 2002). Nevertheless, all of these approaches used artificially ${ }^{13} \mathrm{C}$-labeled substrates. Biogenic methane as a substrate, on the other hand, with its characteristic low carbon isotopic composition can be regarded as a naturally available ${ }^{13} \mathrm{C}$-depleted tracer $\left(\delta^{13} \mathrm{C}\right.$ of methane at Hydrate Ridge: -62 to $-72 \%$; Elvert et al. 2001). This feature enables the evaluation of the activity of specific microbial populations involved in AOM and carbon flow further on into the benthic community (Levin and Michener 2002; Werne et al. 2002).

Mass balance calculations permit the determination of fatty acid patterns accounting for the dilution of the total fatty acid pool by ${ }^{13} \mathrm{C}$-enriched components of sedimentary and other organisms not associated with AOM (Hinrichs et al. 2000). By using this approach we are able to present a corrected fatty acid pattern from the 4-6 cm sediment horizon where aggregate abundance was not biased by Beggiatoa-derived fatty acid signals (Figure 5). The determination of the AOM-dependent portion $f$ in the total fatty acid pool was conducted using the following formula:

$$
\delta^{13} C_{\text {measured fatty acid signal }}=f * \delta^{13} C_{\mathrm{cyC}_{17: 0 \omega 5,6}}+(1-f) * \delta^{13} C_{\text {background fatty acid signal }}
$$

with the carbon isotopic composition of $\mathrm{cyC}_{17: 0 \omega 5,6}$ in the particular sediment horizon as the maximum carbon isotopic fractionation associated with the carbon uptake of SRB during $\mathrm{AOM}$ on one hand ( $=100 \%$ AOM-dependent SRB signal) and background $\delta^{13} \mathrm{C}$ values of every single fatty acid obtained in a reference core without AOM activity from the uppermost sample (0-2 cm depth interval) on the other. Background fatty acid $\delta^{13} \mathrm{C}$ values range from -25 to $-31 \%$ o $\left(\mathrm{C}_{14: 0}\right.$ to $\left.\mathrm{C}_{18: 0}\right)$ with the exception of $\mathrm{C}_{16: 1 \omega 7 \mathrm{c}}(-35 \%), \mathrm{C}_{16: 1 \omega 7 \mathrm{t}}(-46 \%$ ), and $\mathrm{C}_{16: 1 \omega 5 \mathrm{c}}(-42 \%)$; cyC $\mathrm{C}_{17: 0 \omega 5,6}$ was not detected. The cell-specific pattern presented most likely displays a very close resemblance to the real pattern of Desulfosarcina/Desulfococcus species in $\mathrm{AOM}$ consortia. It is clearly dominated by the fatty acid $\mathrm{C}_{16: 1 \omega 5 \mathrm{c}}(43.8 \%)$ and

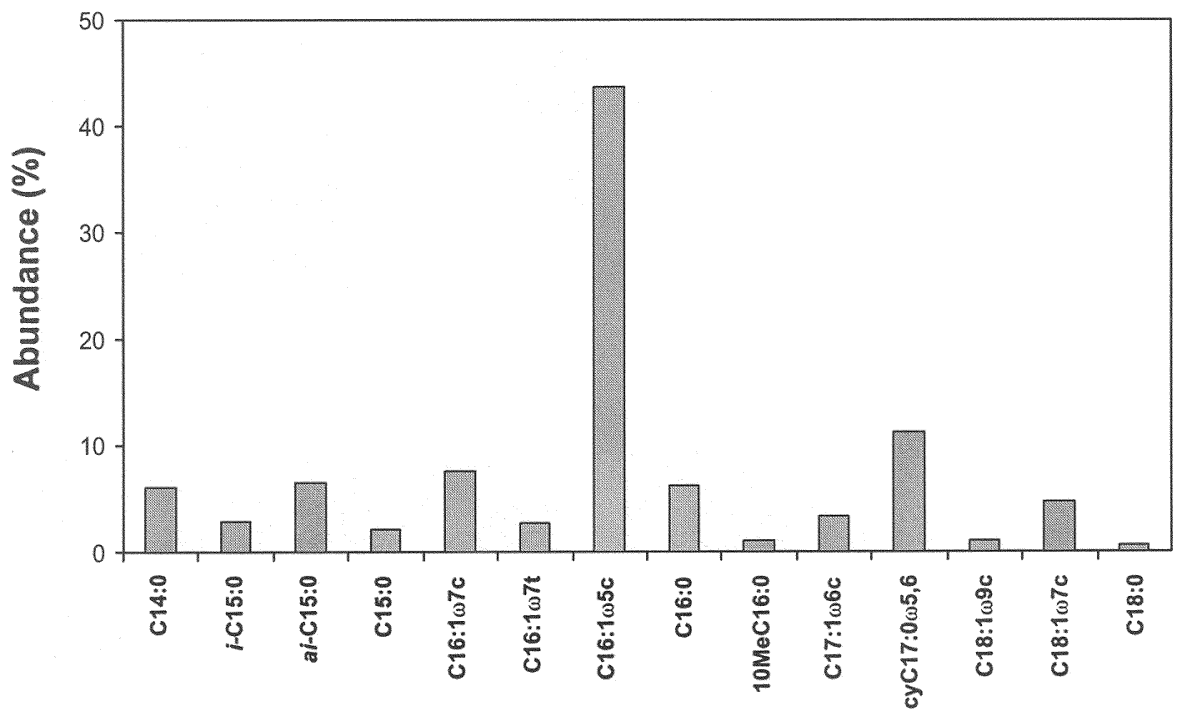

FIGURE 5 Fatty acid pattern of AOM-dependent SRB in the 4-6 cm sediment section. Relative abundance of fatty acids is based on mass balance calculations. 


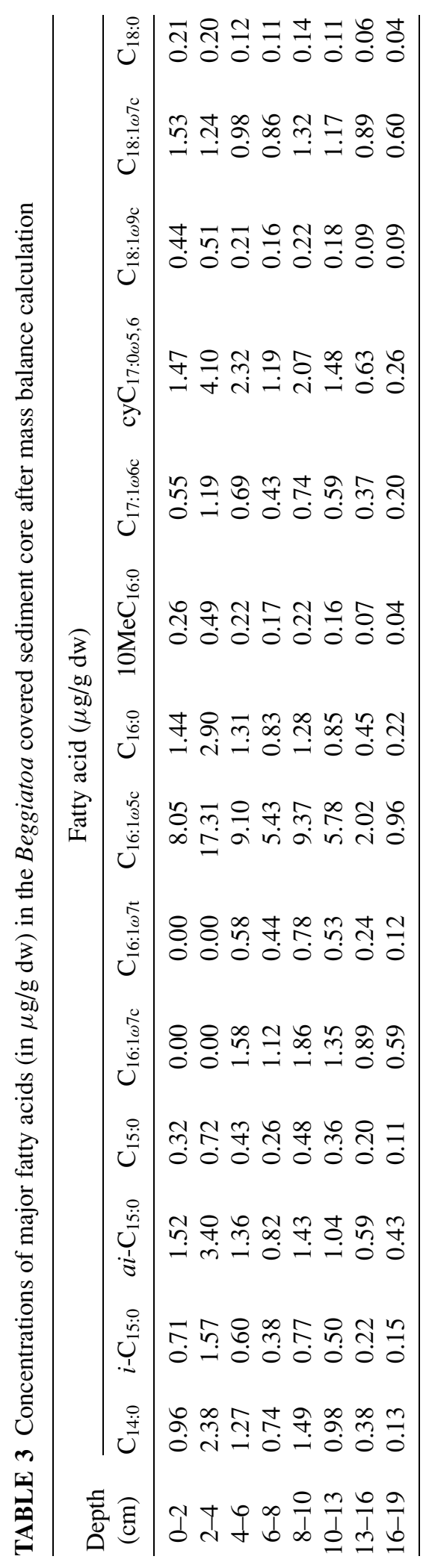


accompanied by significant amounts of $\mathrm{cyC}_{17: 0 \omega 5,6}(11.2 \%)$. Other major fatty acids are $\mathrm{C}_{16: 1 \omega 7 \mathrm{c}}(7.6 \%), i$ - and $a i-\mathrm{C}_{15: 0}\left(2.9 \%\right.$ and $6.5 \%$, respectively), $\mathrm{C}_{16: 0}(6.3 \%), \mathrm{C}_{14: 0}(6.1 \%)$, $\mathrm{C}_{18: 1 \omega 7 \mathrm{c}}(4.7 \%), \mathrm{C}_{17: 1 \omega 6 \mathrm{c}}(3.3 \%)$, and $\mathrm{C}_{16: 1 \omega 7 \mathrm{t}}(2.8 \%)$. In combination with carbon isotope values this finding indicates a high specificity of the fatty acids $C_{16: 1 \omega 5 \mathrm{c}}$ and $\mathrm{cyC}_{17: 0 \omega 5,6}$ whereas $\mathrm{C}_{17: 1 \omega 6 \mathrm{c}}$ seems to be of lesser specificity. Such a fatty acid pattern does not resemble any of the known cultured species of SRB. On the other hand, Peckmann et al. (1999) provided a quite similar fatty acid pattern obtained from a neoformed authigenic aragonite sample in the host rock of the Zechstein group (Harz Mountains, Germany), which was highly enriched in and dominated by the $\mathrm{C}_{16: 1 \omega 5 \mathrm{c}}$ fatty acid $(16.78 \mu \mathrm{g} / \mathrm{g}$ aragonite cement). Although cyC $\mathrm{C}_{17: 0 \omega 5,6}$ was missing and no carbon isotopic measurements have been carried out on the fatty acids, the $\delta^{13} \mathrm{C}$ values of the aragonites of $\sim-10 \%$ very probably point to a recent/subrecent activity of SRB, maybe related to Desulfosarcina/Desulfococcus species.

Based on the mass balance calculations, fatty acid compositions of AOM-dependent SRB of all sediment sections within the Beggiatoa covered sediment core are presented in Table 3. The calculations suggest that up to $63 \%$ of the total fatty acids are derived from SRB involved in AOM and more specifically, up to $95 \%$ of the $\mathrm{C}_{16: 1 \omega 5 \mathrm{c}}$ fatty acid signal is produced by species members of the genus Desulfosarcina/Desulfococcus. The latter estimate is in the similar range as obtained by FISH analyses, quantifying the amount of Desulfosarcina/Desulfococcus species in a replicate sediment core at station 19-2 (see Knittel et al. 2003 , this issue). Assuming that the corrected depth profile of $\mathrm{C}_{16: 1 \omega 5 \mathrm{c}}$ represents a pure signal of viable cells in the sediment column, an estimate of the amount of specific fatty acid content per SRB cell is possible. Normalizing the amount of $\mathrm{C}_{16: 1 \omega 5 \mathrm{c}}$ in the upper $8 \mathrm{~cm}$ of the sediment core to the number of SRB cells in AOM aggregates, there are 0.46 to $0.58 \times$ $10^{-15} \mathrm{~g} \mathrm{C}_{16: 1 \omega 5 \mathrm{c}}$ per viable SRB cell. The amount of fatty acid cyC $\mathrm{C}_{17: 0 \omega 5,6}$ (AOM-dependent SRB signal $=100 \%$ ) ranges from 0.10 to $0.14 \times 10^{-15} \mathrm{~g}$ per cell SRB. In this particular sediment zone correlation coefficients between the specific fatty acid contents-corrected ones used for $\mathrm{C}_{16: 1 \omega 5 \mathrm{c}}$, by definition uncorrected ones used for cy $\mathrm{C}_{17: 0 \omega 5,6}$ - and aggregate number are significantly increased $\left(r^{2}\left[\mathrm{C}_{16: 1 \omega 5 \mathrm{c}}\right]=0.93 ; r^{2}\left[\mathrm{cyC}_{17: 0 \omega 5,6}\right]=0.99\right)$. Between 8 and $10 \mathrm{~cm}$ sediment depth, the amount of $\mathrm{C}_{16: 1 \omega 5 \mathrm{c}}$ and $\mathrm{cyC}_{17: 0 \omega 5,6}$ fatty acid per SRB cell increases five times to 2.50 and $0.55 \times 10^{-15} \mathrm{~g}$, respectively, maybe indicating nonviable or starved cells because of depleted sulfate concentrations and, thus, of less favorable conditions for AOM aggregates in this sediment interval. The lesser correlation between specific fatty acid content and aggregate abundance in the $8-10 \mathrm{~cm}$ sediment section may also suggest that Desulfosarcina/Desulfococcus species here are only partially functioning as partners in AOM aggregates. Nevertheless, the cell-specific estimates may be used in the future to calculate the number of Desulfosarcina/Desulfococcus cells in AOM consortia and sediments from membrane fatty acid analysis alone.

\section{Summary}

Depth profiles of abundant specific fatty acids (i.e., $\mathrm{C}_{16: 1 \omega 5 \mathrm{c}}, \mathrm{cyC}_{17: 0 \omega 5,6}$ ) and numbers of AOM aggregates in combination with pore water sulfate show a very good correlation in anaerobic gas hydrate-bearing sediments. These unusual fatty acids can be used as chemotaxonomic markers of AOM-dependent DesulfosarcinalDesulfococcus species, both members of the family Desulfobacteraceae. Averaging ${ }^{13} \mathrm{C}$-depleted carbon isotope values of $-90 \%$ o $\left(\mathrm{C}_{16: 1 \omega 5 \mathrm{c}}\right)$ and $-100 \%$ ( $\left.\mathrm{cyC}_{17: 0 \omega 5,6}\right)$ are indicative of methane carbon flowing via methanotrophic archaea to the SRB. In the matching zone of specific fatty acids and aggregate number mass balance calculations enable not only the determination of a cell-specific fatty acid pattern, but they also allow the estimate of specific fatty acid content per viable Desulfosarcina/Desulfococcus cell. The values range between 0.46 to $0.58 \times 10^{-15} \mathrm{~g}$ for 
$\mathrm{C}_{16: 1 \omega 5 \mathrm{c}}$ and 0.10 to $0.14 \times 10^{-15} \mathrm{~g}$ for cyC $\mathrm{C}_{17: 0 \omega 5,6}$. These estimates may be used in the future to calculate the number of Desulfosarcina/Desulfococcus cells in AOM aggregates and sediments.

\section{References}

Alexandrino M, Knief C, Lipski A. 2001. Stable-isotope-based labeling of styrene-degrading microorganisms in biofilters. Appl Environ Microbiol 67:4796-4804.

Boetius A, Ravenschlag K, Schubert C, Rickert D, Widdel F, Gieseke A, Amann R, Jørgensen BB, Witte U, Pfannkuche O. 2000. A marine microbial consortium apparently mediating anaerobic methane of oxidation. Nature 407:623-626.

Bohrmann G, Greinert J, Suess E, Torres M. 1998. Authigenic carbonates from Cascadia subduction zone and their relation to gas hydrate stability. Geology 26:647-650.

Boschker HTS, Middelburg JJ. 2002. Stable isotopes and biomarkers in microbial ecology. FEMS Microbiol Ecol 40:85-95.

Boschker HTS, Nold SC, Wellsbury P, Bos D, de Graaf W, Pel R, Parkes RJ, Cappenberg TE. 1998. Direct linking of microbial populations to specific biogeochemical processes by ${ }^{13} \mathrm{C}$-labelling of biomarkers. Nature 392:801-805.

Bull ID, Parekh NR, Hall GH, Ineson P, Evershed RP. 2000. Detection and classification of atmospheric methane oxidizing bacteria in soil. Nature 405:175-178.

Crossmann ZM, McNamara N, Parekh N, Ineson P, Evershed RP. 2001. A new method for identifying the origins of simple and complex hopanoids in sedimentary materials using stable isotope labelling with ${ }^{13} \mathrm{CH}_{4}$ and compound specific stable isotope analyses. Organic Geochem 32:359364.

Dowling NJE, Widdel F, White DC. 1986. Phospholipid ester-linked fatty acid biomarkers of acetateoxidizing sulphate-reducers and other sulphide-forming bacteria. J Gen Microbiol 132:18151825.

Elvert M, Greinert J, Suess E, Whiticar MJ. 2000. Archaea mediating anaerobic methane oxidation in deep-sea sediments at cold seeps of the eastern Aleutian subduction zone. Organic Geochem 31:1175-1187.

Elvert M, Greinert J, Suess E, Whiticar MJ. 2001. Carbon isotopes of biomarkers derived from methane-oxidizing microbes at Hydrate Ridge, Cascadia convergent margin. In: Paull CK, Dillon WP, editors. Natural Gas Hydrates: Occurrence, Distribution, and Dynamics. Vol. 124. Washington, DC: American Geophysical Union. p 115-129.

Elvert M, Suess E, Whiticar MJ. 1999. Anaerobic methane oxidation associated with marine gas hydrates: superlight $\mathrm{C}$-isotopes from saturated and unsaturated $\mathrm{C}_{20}$ and $\mathrm{C}_{25}$ irregular isoprenoids. Naturwissenschaften 86:295-300.

Fay L, Richli U. 1991. Location of double bonds in polyunsaturated fatty acids by gas chromatographymass spectrometry after 4,4-dimethyloxazoline derivatization. J Chromatogr 541:89-98.

Greinert J, Bohrmann G, Suess E. 2001. Gas hydrate-associated carbonates and methane-venting at Hydrate Ridge: classification, distribution, and origin of authigenic lithologies. In: Paull CK, Dillon WP, editors. Natural Gas Hydrates: Occurrence, Distribution, and Dynamics. Vol. 124. Washington, DC: American Geophysical Union. p 99-113.

Grogan DW, Cronan Jr JE. 1997. Cyclopropane ring formation in membrane lipids of bacteria. Microbiol Mol Biol Rev 61:429-441.

Hanson J, Macalady J, Harris D, Scow K. 1999. Linking toluene degradation with specific microbial populations in soil. Appl Environ Microbiol 65:5403-5408.

Hinrichs K-U, Hayes JM, Sylva SP, Brewer PG, DeLong EF. 1999. Methane-consuming archaebacteria in marine sediments. Nature 398:802-805.

Hinrichs K-U, Summons RE, Orphan V, Sylva S, Hayes JM. 2000. Molecular and isotopic analysis of anaerobic methane-oxidizing communities in marine sediments. Organic Geochem 31:16851701.

Johnson AR, Winding A, Karlson U, Roslev P. 2002. Linking of microorganisms to phenanthrene metabolism in soil by analysis of ${ }^{13} \mathrm{C}$-labeled cell lipids. Appl Environ Microbiol 68:6106-6113. 
Knittel K, Boetius A, Lemke A, Eilers H, Lochte K, Pfannkuche O, Amann R. 2003. Activity, distribution, and abundance of sulfate reducers and other bacteria in sediments above gas hydrate (Cascadia Margin, OR). Geomicrobiol J 20:269-294.

Knoblauch C, Sahm K, Jørgensen BB. 1999. Psychrophilic sulfate-reducing bacteria isolated from permanently cold arctic marine sediments: description of Desulfofrigus oceanense gen. nov., sp. nov., Desulfofrigus fragile sp. nov., Desulfofaba gelida gen. nov., sp. nov., Desulfotalea psychrophila gen. nov., sp. nov. and Desulfotalea arctica sp. nov. Int J System Bacteriol 49:16311643.

Kohring LL, Ringelberg DB, Devereux R, Stahl DA, Mittelman MW, White DC. 1994. Comparison of phylogenetic relationships based on phospholipid fatty acid profiles and ribosomal RNA sequence similarities among disimilatory sulfate-reducing bacteria. FEMS Microbiol Lett 119:303-308.

Kuever J, Könneke M, Galushko A, Drzyzga O. 2001. Reclassification of Desulfobacterium phenolicum as Desulfobacula phenolica comb. nov. and description of strain $\mathrm{Sax}^{\mathrm{T}}$ as Desulfotignum balticum gen. nov., sp. nov. Int J System Evolution Microbiol 51:171-177.

Kulm LD, Suess E, Moore JC, Carson B, Lewis BT, Ritger SD, Kadko DC, Thornburg TM, Embley RW, Rugh WD, Massoth GJ, Langseth MG, Cochrane GR, Scanman RL. 1986. Oregon subduction zone: venting, fauna, and carbonates. Science 231:561-566.

Levin LA, Michener RH. 2002. Isotopic evidence for chemosynthesis-based nutrition of macrobenthos: the lightness of being at Pacific methane seeps. Limnol Oceanog 47:1336-1345.

Michaelis W, Seifert R, Nauhaus K, Treude T, Thiel V, Blumenberg M, Knittel K, Giesecke A, Peterknecht K, Pape T, Boetius A, Amann R, Jørgensen BB, Widdel F, Peckmann J, Pimenov NV, Gulin MB. 2002. Microbial reefs in the Black Sea fueled by anaerobic oxidation of methane. Science 297:1013-1015.

Nauhaus K, Boetius A, Krüger M, Widdel F. 2002. In vitro demonstration of anaerobic oxidation of methane coupled to sulphate reduction in sediment from a marine gas hydrate area. Environ Microbiol 4:296-305.

Nichols PD, Guckert JB, White DC. 1986. Determination of monounsaturated fatty acid double-bond position and geometry for microbial monocultures and complex consortia by capillary GC-MS of their dimethyl disulphide adducts. J Microbiol Meth 5:49-55.

Orphan VJ, Hinrichs K-U, Ussler III W, Paull CK, Taylor LT, Sylva SP, Hayes JM, DeLong EF. 2001. Comparative analysis of methane-oxidizing archaea and sulfate-reducing bacteria in anoxic marine sediments. Appl Environ Microbiol 67:1922-1934.

Pancost RD, Bouloubassi I, Aloisi G, Sinninghe Damsté JS, the Medinaut Shipboard Scientific Party. 2001a. Three series of non-isoprenoidal dialkyl glycerol diethers in cold-seep carbonate crusts. Organic Geochem 32:695-707.

Pancost RD, Hopmans EC, Sinninghe Damsté JS, the Medinaut Shipboard Scientific Party. 2001b. Archaeal lipids in Mediterranean cold seeps: molecular proxies for anaerobic methane oxidation. Geochim Cosmochim Acta 65:1611-1627.

Pancost RD, Sinninghe Damsté JS, de Lint S, van der Maarel MJEC, Gottschal JC, the Medinaut Shipboard Scientific Party. 2000. Biomarker evidence for widespread anaerobic methane oxidation in Mediterranean sediments by a consortium of methanogenic archaea and bacteria. Appl Environ Microbiol 66:1126-1132.

Parkes RJ, Calder AG. 1985. The cellular fatty acids of three strains of Desulfobulbus, a propionateutilising sulphate-reducing bacterium. FEMS Microbiol Ecol 31:361-363.

Peckmann J, Paul J, Thiel V. 1999. Bacterially mediated formation of diagenetic aragonite and native sulfur in Zechstein carbonates (Upper Permian, Central Germany). Sediment Geol 126:205-222.

Ritger S, Carson B, Suess E. 1987. Methane-derived authigenic carbonates formed by subductioninduced pore-water expulsion along the Oregon/Washington margin. Geol Soc Amer Bull 98:147-156.

Rütters H, Sass H, Cypionka H, Rullkötter J. 2001. Monoalkylether phospholipids in the sulfatereducing bacteria Desulfosarcina variabilis and Desulforhadus amnigenus. Arch Microbiol 176:435-442.

Rütters H, Sass H, Cypionka H, Rullkötter J. 2002. Phospholipid analysis as a tool to study complex microbial communities in marine sediments. J Microbiol Meth 48:149-160. 
Sass A, Rütters H, Cypionka H, Sass H. 2002. Desulfobulbus mediterraneus sp. nov., a sulfate-reducing bacterium growing on mono- and disaccharides. Arch Microbiol 177:468-474.

Schouten S, Wakeham SG, Sinninghe Damsté JS. 2001. Evidence for anaerobic methane oxidation by archaea in euxinic waters of the Black Sea. Organic Geochem 32:1277-1281.

Spitzer V. 1997. Structure analysis of fatty acids by gas chromatography-low resolution electron impact mass spectrometry of their 4,4-dimethyloxazoline derivatives-a review. Prog Lipid Res 35:387-408.

Suess E, Torres ME, Bohrmann G, Collier RW, Greinert J, Linke P, Rehder G, Trehu A, Wallmann K, Winckler G, Zuleger E. 1999. Gas hydrate destabilization: enhanced dewatering, benthic material turnover and large methane plumes at the Cascadia convergent margin. Earth Planet Sci Lett 170:1-15.

Suess E, Torres ME, Bohrmann G, Collier RW, Rickert D, Goldfinger C, Linke P, Heuser A, Sahling H, Heeschen K, Jung C, Nakamura K, Greinert J, Pfannkuche O, Trehu A, Klinkhammer G, Whiticar MJ, Eisenhauer A, Teichert B, Elvert M. 2001. Sea floor methane hydrates at Hydrate Ridge, Cascadia margin. In: Paull CK, Dillon WP, editors. Natural Gas Hydrates: Occurrence, Distribution, and Dynamics. Vol. 124. Washington, DC: American Geophysical Union. p 87-98.

Taylor J, Parkes RJ. 1983. The cellular fatty acids of the sulphate-reducing bacteria, Desulfobacter sp., Desulfobulbus sp. and Desulfovibrio desulfuricans. J Gen Microbiol 129:3303-3309.

Thiel V, Peckmann J, Richnow HH, Luth U, Reitner J, Michaelis W. 2001. Molecular signals for anaerobic methane oxidation in Black Sea seep carbonates and a microbial mat. Mar Chem 73:97-112.

Thiel V, Peckmann J, Seifert R, Wehrung P, Reitner J, Michaelis W. 1999. Highly isotopically depleted isoprenoids: molecular markers for ancient methane venting. Geochim Cosmochim Acta 63:3959-3966.

Torres ME, Mcmanus J, Hammond DE, de Angelis MA, Heeschen KU, Colbert SL, Tryon MD, Brown KM, Suess E. 2002. Fluid and chemical fluxes in and out of sediments hosting methane hydrate deposits on Hydrate Ridge, OR, I: hydrological provinces. Earth Planet Sci Lett 201:525-540.

Treude T, Boetius A, Knittel K, Rickert D, Jørgensen BB. submitted. Anaerobic oxidation of methane above gas hydrates (Hydrate Ridge, OR). Marine Ecology Progress Series.

Vainshtein M, Hippe H, Kroppenstedt RM. 1992. Cellular fatty acid composition of Desulfovibrio species and its use in classification of sulfate-reducing bacteria. System Appl Microbiol 15:544566.

Werne JP, Baas M, Sinninghe Damsté JS. 2002. Molecular isotopic tracing of carbon flow and trophic relationships in a methane-supported benthic microbial community. Limnol Oceanogr 47:16941701.

Whiticar MJ. 1999. Carbon and hydrogen isotope systematics of bacterial formation and oxidation of methane. Chem Geol 161:291-314.

Zhang CL, Li Y, Wall JD, Larsen L, Sassen R, Huang Y, Wang Y, Peacock A, White DC, Horita J, Cole DR. 2002. Lipid and carbon isotopic evidence of methane-oxidizing and sulfate-reducing bacteria in association with gas hydrates from the Gulf of Mexico. Geology 30:239-242. 